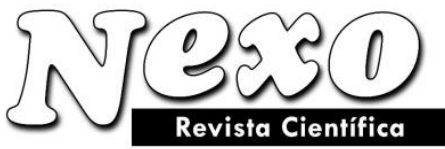

ISSN-E 1995-9516

Universidad Nacional de Ingeniería COPYRIGHT @ (UNI). TODOS LOS DERECHOS RESERVADOS http://revistas.uni.edu.ni/index.php/Nexo https://doi.org/10.5377/nexo.v34i06.13134

\title{
Quality of electricity in power supply of non-traction consumers of railway transport
}

\section{Calidad de la electricidad en el suministro eléctrico de los consumidores de transporte ferroviario sin tracción}

\author{
Denis N. Morgunov, Leonid S. Labunsky* \\ Samara State Transport University. Samara, Russian Federation. \\ *Corresponding author E-mail: labunski@yandex.ru
}

(recibido/received: 22-septiembre-2021; aceptado/accepted: 02-diciembre-2021)

\begin{abstract}
The article presents the results of the study of the influence of LED lamps with switching power supplies containing power factor correctors on the quality of electricity in the power supply system of non-traction consumers of railway transport. It is noted that the emission of harmonic components of current by electronic loads can cause deviations in the quality of electricity up to the occurrence of emergency situations due to overloads of low $(0.4 \mathrm{kV})$ and medium $(6 / 10 \mathrm{kV})$ voltage networks. A non-linear electronic load (LED lamp), although equipped with a power factor corrector, causes the generation of a significant level of current harmonics, which significantly affect the operation of the transformer. As a result, the transformer, calculated taking into account the load factor of $0.7-0.8$, can not be normally operated in the conditions of using electronic load devices. Mathematical modeling of the correction of the modes of the power supply system with nonlinear single-phase loads is performed, provided that the correction devices made on the basis of several condensers and reactors with nonlinear characteristics are used to balance the modes.
\end{abstract}

Keywords: Electricity quality; Lamps; Switching power supplies.

\section{RESUMEN}

El artículo presenta los resultados del estudio de la influencia de las lámparas LED con fuentes de alimentación conmutadas que contienen correctores del factor de potencia sobre la calidad de la electricidad en el sistema de suministro de energía de los consumidores sin tracción del transporte ferroviario. Se observa que la emisión de componentes armónicos de corriente por cargas electrónicas puede ocasionar desviaciones en la calidad de la electricidad hasta la ocurrencia de situaciones de emergencia por sobrecargas de redes de baja $(0.4 \mathrm{kV})$ y media $(6 / 10 \mathrm{kV})$ de tensión. Una carga electrónica no lineal (lámpara LED), aunque equipada con un corrector de factor de potencia, provoca la generación de un nivel significativo de armónicos de corriente, que afectan significativamente el funcionamiento del transformador. Como resultado, el transformador, calculado teniendo en cuenta el factor de carga de $0,7-0,8$, no se puede operar normalmente en las condiciones de uso de dispositivos de carga electrónicos. Se realiza el modelado matemático de la corrección de los modos del sistema de alimentación con cargas monofásicas no lineales, siempre que los dispositivos de corrección realizados en base a varios condensadores y reactores con características no lineales se utilicen para equilibrar los modos.

Palabras claves: Calidad de la electricidad; Lámparas; Fuentes de alimentación conmutadas. 


\section{INTRODUCTION}

The development of energy efficiency technologies in lighting contributes to an increase in the share of consumers using switching power supplies in electric networks. Various programs and strategies of energy efficiency, including energy strategy of JSC "Russian Railways" in the future up to 2030 and the Russian Federation Federal law No. 261-FZ "On energy saving and increasing energy efficiency" (State Duma of the Federal Assembly of the Russian Federation, 2009), require the introduction and replacement of existing types of lighting devices and settings (incandescent lamps, mercury-filled lamps, metal halide lamps, sodium lamps), on modern LED lamps.

Annual analyses of the operation of the power supply facilities of the Russian Railways show that the share of electricity consumption by non-traction consumers is about $14 \%$ of the total electricity consumption in JSC "Russian Railways", so technical solutions to improve energy efficiency (Andronchev et al., 2020; Garanin et al., 2017; Mitrofanov et al., 2020a, 2020b) in both traction and non-traction energetics can bring the company a large profit. However, both in operation and in the planned power supply systems for nontraction consumers of railway transport, the influence of switching power supplies of LED lamps on the quality of electricity is not sufficiently taken into account.

The quality of power supply plays an important role for the reliability of all consumers' work on the railway networks, including non-traction ones. Unacceptable deviations in electricity quality indicators (EQI) can cause a failure in the operation of such non-traction consumers as railway automation and telemechanics devices; the safety of train traffic directly depends on such devices.

The introduction of LED equipment at the infrastructure facilities of JSC "Russian Railways" is carried out throughout the road network, but many design institutes and operating organizations do not take into account the harm that installations with nonlinear switching power supplies can bring along with increasing efficiency (Morgunov, 2016; Morgunov and Labunsky, 2018a, 2018b). The emission of harmonic components of current by electronic loads (EL) can cause deviations from the regulatory requirements of the electricity quality (EQ), and in some cases, a source of accidents due to overloads of the current distribution network (CDN).

When designing lighting according to existing methods, the choice of the power of the supply transformer is determined by the lighting power consumption in accordance with NTP EPP-94 "Design of power supply of industrial enterprises" (Tyazhpromelektroproyekt, 1994). But a non-linear EL (LED lamp), although equipped with a power factor corrector (PFC), causes the generation of a significant level of current harmonics that significantly affect the operation of the transformer. As a result, the transformer, calculated taking into account the load factor of 0.7-0.8, can not be operated normally in the conditions of using EN devices.

\section{LITERATURE REVIEW}

The issues of the influence of EQ on the work efficiency of various types of electrical equipment are considered in sufficient detail in the works of Tretyakov (2005) "Assessment of the influence of the technological equipment composition of non-traction railway consumers of electric energy on the sinusoidality of supply voltages"; Grishechko (2008) "Improvement of methods for monitoring the quality indicators of electricity of power supply systems for non-traction consumers of electrified roads"; Malysheva (2011) "Optimization of the composition and parameters of compensating devices in the electric networks of non-traction railway consumers". In these works, a significant number of theoretical and experimental studies are devoted to assessing the influence of EL (electric drive, converters, electric arc furnaces, etc.) on EQ.

It should be noted that in these works the influence of powerful EL on electric networks is considered. But, due to the prevailing opinion about its insignificance, the influence of the EL of low-power switching power supplies 
with a high frequency of signal modulation is not considered. The significant growth of such an EL on the road networks, the peculiarities of its current consumption and its modulation, is of great interest and requires a separate study of this phenomenon.

\section{METHODOLOGY}

Methods of mathematical and full-scale modeling, direct measurements of EQ in determining the influence of switching power supplies with PFC with a high frequency of signal modulation were used in the study. The object of the study was the power supply system for non-traction consumers of railway transport in terms of power supply for lighting installations. The subject of the study was the electromagnetic processes occurring in the three-phase network of the power supply system for non-traction consumers, methods for assessing the influence of low-power switching power supplies with PFC with a high frequency of signal modulation on the generation of current harmonics and EQ. Measurements of the harmonics of the current in a three-phase network under its load by single-phase LED lamps with different types of power sources were performed. A device for compensating non-linearity in the load node of a three-phase electric network with EL is developed. The results of mathematical calculations were verified using the NI MULTISIM 10 computer program. Variants of switching schemes and determination of the permissible load factor of transformers are proposed.

\section{RESULTS}

For the first time, a significant influence of LED lighting devices with a switching power supplies with PFC with a high frequency of signal modulation was revealed during the implementation of the project for the reconstruction of the lighting of the road tunnel through Dzhalgan Mountain 936+251 km of the R-217 "Caucasus" automobile road of the M-4 "Don" highway in the Republic of Dagestan, performed by PTP "EnergoStandart" in accordance with the requirements of NTP EPP-94.

In the three-phase tunnel lighting network, powered by a separate TM25/6/0.4 transformer, with a uniform phases load by LED lamps, strong distortions of the voltage and current form were detected, with the transformer load factor significantly less than the calculated one (Morgunov, 2017). Graphs of distortions and harmonic intensity measurements are shown in Figure 1.

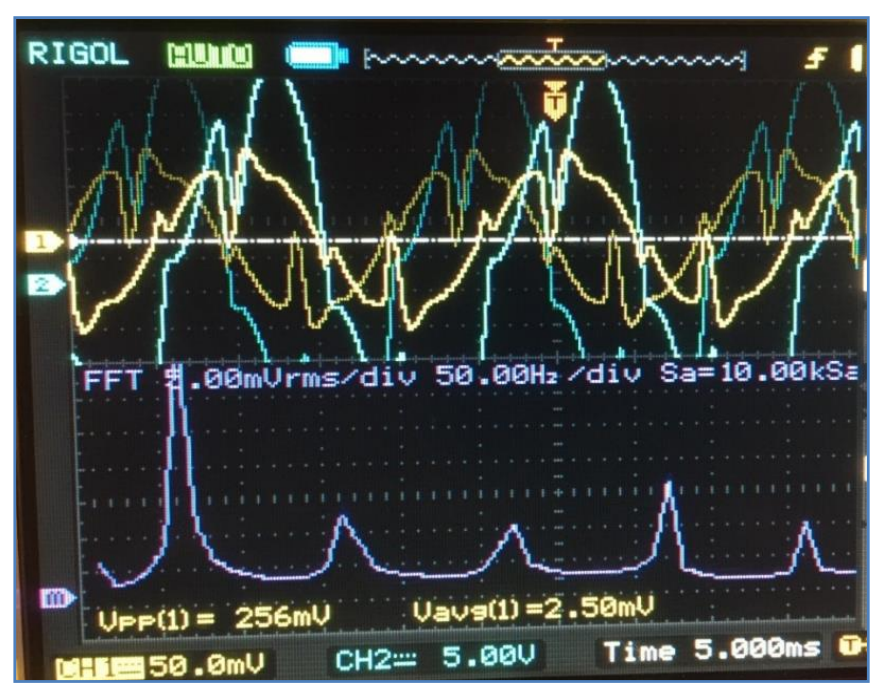

Figure 1. Graphs of distortions and harmonic intensity measurements. 
To identify the cause of this phenomenon, the parameters of LED lamps declared by the manufacturers are analyzed: the power factor and the features of the operation of the PFC of such lamps.

The PFC used in LED lamps brings the phase shift between the current and the voltage of the source to zero and forms a pseudo-sinusoidal form of the current consumed from the network.

As a result of the study, it was determined that such a principle of forming a pseudosinusoidal current form leads to the superposition of high-frequency current components in each phase and the mutual influence of the phases. Power sources of LED lamps with PFC, even evenly distributed over the phases of a three-phase network, cause an increase in reactive power consumption and overload of the supply transformer.

To eliminate these negative effects, a mathematical simulation of the correction of the modes of the power supply system with nonlinear single-phase loads was performed, provided that correction devices (CD) made on the basis of several condensers and reactors with nonlinear characteristics are used to balance the modes (Tyazhpromelektroproyekt, 1994).

This problem was solved using the harmonic balance method and a certain approach, which consists in compensating the nonlinearity of a single-phase load $Z_{H}(t)$ by connecting a compensating nonlinear element in parallel to it $Z_{K}(t)$, and the characteristic of the compensating nonlinear element $C_{K}(t)$ or $L_{K}(t)$ has a given analytical representation in the form of polynomials.

As a result, a compensating current $i_{k}(t)$ is created, which in total with the load current $i_{H}(t)$ gives a sinusoidal function.

$$
\mathrm{i}_{K}(t)=A_{K 1} \cos w t+B_{K 1} \sin w t-\sum_{s=2}^{n}\left(A_{H s} \operatorname{coss} w t+B_{H s} \sin s w t\right)
$$

According to the required value of the compensating current, the parameters of the linear control elements were calculated:

$$
\begin{gathered}
w C=\frac{\left(U_{0} w C_{0}+\frac{w A_{2}}{2} U_{0}+B_{H 1}\right) \sin \left(\frac{2 \pi}{3}-\theta\right)-\left(\mathrm{A}_{1 H}-\frac{U_{0} w B_{2}}{2}\right) \cos \left(\frac{2 \pi}{3}-\theta\right)}{U_{0} \cos \left(\frac{5 \pi}{6}-\theta\right)} \\
w L=\frac{-U_{0} \cos \left(\frac{5 \pi}{6}+\theta\right)}{\left(A_{1 H}-\frac{U_{0} w B_{2}}{2}\right) \cos \left(\frac{2 \pi}{3}+\theta\right)+\left(U_{0} w C_{0}+\frac{w A_{2}}{2} U_{0}+B_{1 H}\right) \sin \left(\frac{2 \pi}{3}+\theta\right)}
\end{gathered}
$$

The considered method of compensation of nonlinearities in the load node makes it possible to synthesize the balancing circuits of the $\mathrm{CD}$ with one physically realizable compensating nonlinear reactive element at an optional setting of the load characteristics (Tretyakov, 2005).

The developed mathematical model was tested using THE NI MULTISIM 10 program. 
The results of the modelling of current and voltage distortion in the three-phase network (Figure 3) show distortions of up to $53 \%$, which corresponds to the measurements made in the road tunnel through Dzhalgan Mountain.

Next, G-shaped LC filters were calculated, which were added to the model of a three-phase lighting network with LED lamps. As a result, the voltage distortions in the three-phase network decreased to less than $10 \%$.

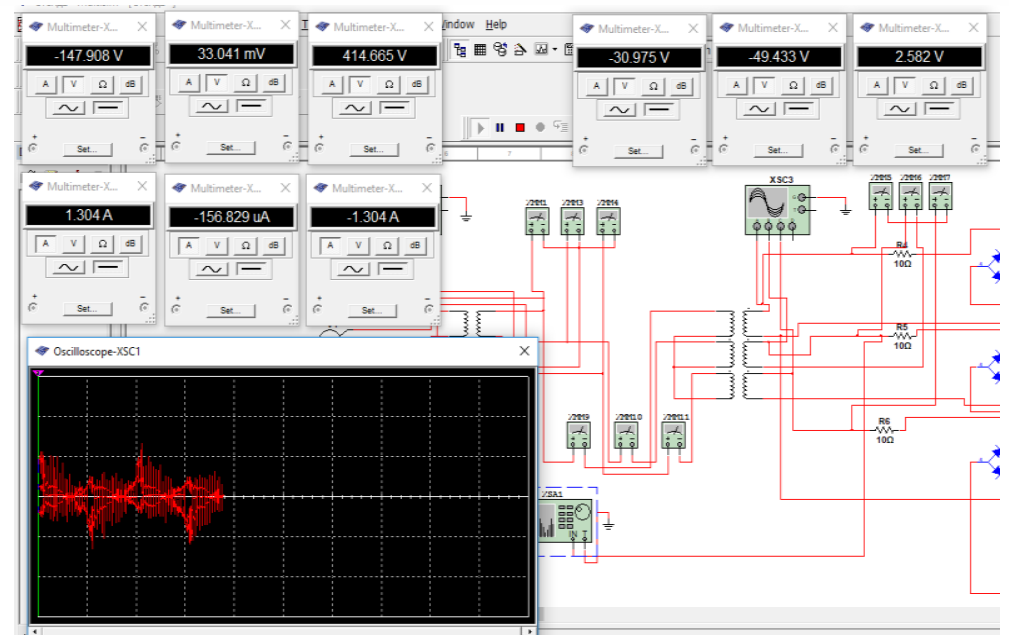

Figure 3. Modelling results of current and voltage distortions in a three-phase network with LED lights.

\section{CONCLUSION}

Power sources of LED lamps with PFC, even evenly distributed over the phases of the three-phase network, cause an increase in reactive power consumption and overload of the supply transformer, selected taking into account the load factor of 0.7-0.8 in accordance with the NTP EPP-94 "Design of power supply of industrial enterprises" (Tyazhpromelektroproyekt, 1994). A non-linear EL (LED lamp), even equipped with a power factor corrector (PFC), causes the generation of a significant level of current harmonics that significantly affect the operation of the transformer. Compliance of switching power supplies with the State Standard of the Russian Federation for electromagnetic compatibility does not give grounds for use in the design of lighting systems, based on the technical data of manufacturers datasheet. Increasing the power factor by using an active power corrector in a three-phase lighting network, in most cases, does not reduce the harmonic components, but exacerbates the voltage distortions. As a result, the transformer that supplies the lighting network cannot be operated normally.

The problem of voltage and current distortion was firstly identified at the lighting facility of the road tunnel through Dzhalgan. This object became a full-scale example and a basis for studying the problem of the influence of LED lighting devices on the quality of electricity. As a result of the research, a mathematical model of the device for compensating non-linearity in the load node of a three-phase network with nonlinear single-phase loads was developed. In THE NI MULTISIM 10 program, the electrical circuit of the lighting system is modeled. The values of voltage and current distortion measured at the object from the influence of real loads using the switching power supplies with PFC were confirmed. G - shaped LC filters were calculated, which were added to the original model. The results of reducing distortions and improving the quality of electricity are obtained. 


\section{REFERENCES}

Andronchev, I. K., Asabin, V. V., Kossov, E. E., Gordeev, I. P., Tselikovskaia, V. S. and Plokhov, E. M. (2020). The energy performance efficiency of locomotives. Russian Electrical Engineering, 3 (91), 175178.

Garanin, M. A., Mitrofanov, A. N. and Dobrynin, E. V. (2017). Taking into account electrical connection between traction substations in calculation of electrified-railroad capacity. Russian Electrical Engineering, 3 (88), 186-190.

Grishechko, S. V. (2008). Improvement of control methods of quality indicators of electric energy of power supply systems of non-traction consumers of electrified roads: Extended abstract of dissertation. Omsk State Transport University, Omsk, Russia.

Malysheva, N. N. (2011). Optimization of the composition and parameters of compensating devices in the electric networks of non-traction railway consumers: Extended abstract of dissertation. Omsk State Transport University, Omsk, Russia.

Mitrofanov, A. N., Asabin, V. V., Mitrofanov, S. A., Plokhov, E. M. and Gordeev, I. P. (2020a). The effect of energy-supply and performance indicators on the performance of traction-resource management centers. Russian Electrical Engineering, 3 (91), 166-170.

Mitrofanov, A. N., Dobrynin, E. V. and Mitrofanov, S. A. (2020b). An algorithm for generating sets of acceptable energy supply values for intelligent systems for carrying heavy trains. Russian Electrical Engineering, 3 (91), 186-190.

Morgunov, D. N. (2016). Advantages and disadvantages of LED lighting. Science, Technology, and Education, 5 (23), 55-59.

Morgunov, D. N. (2017). Effect of non-linear load on the quality of the electrical network. Problems of Modern Science and Education, 17 (99), 39-43.

Morgunov, D. N. and Labunsky, L. S. (2018a). Compensation of non-linearity in the load node. In: International Scientific and Practical Conference "Problems and Prospects of Experimental Science Development" (pp. 151-155). Tyumen, Russia: Omega Science.

Morgunov, D. N. and Labunsky, L. S. (2018b). Correction of modes of three-phase systems with nonlinear loads. Achievement of Science and Education, 18 (40), 7-10.

State Duma of the Federal Assembly of the Russian Federation. (2009). Federal Law No. 261-FZ of 25.11.2009 "On energy saving and energy efficiency Improvement and on amendments to certain legislative acts of the Russian Federation" (as amended on 26.07.2019). Sobranie Zakonodatel'stva Rossiiskoi Federatsii [SZ RF] [Collection of Legislation of the RF] 30.11.2009, No. 48, Item 5711.

Tretyakov, E. (2005). Assessment of the influence of the technological equipment composition of non-traction railway consumers of electric energy on the sinusoidality of supply voltages: Extended abstract of dissertation. Omsk State Transport University, Omsk, Russia.

Tyazhpromelektroproyekt. (1994). NTP EPP 94 Power Supply Design for Industrial Facilities. Retrieved March 21, 2021, from https://files.stroyinf.ru/Data2/1/4294847/4294847066.htm 